\title{
Non-Destructive Experimental Method for Determination of Modulus of Elasticity of Hydraulic Hoses
}

Lumír Hružík ${ }^{1}$, Adam Bureček ${ }^{1}$, Martin Vašina ${ }^{1}$, Ondřej Bílek ${ }^{2}$

${ }^{1}$ Faculty of Mechanical Engineering, VSB-Technical University of Ostrava. 17. listopadu 15/2172, 70833 Ostrava-Poruba.Czech Republic.E-mail: adam.burecek@vsb.cz, lumir.hruzik@vsb.cz, martin.vasina@vsb.cz

${ }^{2}$ Faculty of Technology, TBU in Zlín, Nám. T. G. M. 5555, 76001 Zlín. Czech Republic. E-mail: bilek@ft.utb.cz

This article deals with a non-destructive experimental method for determination of modulus of elasticity of hydraulic hoses. There is described experimental equipment for determination of the modulus of elasticity of hydraulic hoses by expansion method. The modulus of elasticity is determined for several hydraulic hoses of different parameters on basis of combined hydraulic capacity of oil and hose. Furthermore it is necessary to know oil bulk modulus. The modulus of elasticity of hoses is very important during design of a hydraulic system. It is necessary to take into account the modulus of elasticity of hoses in a mathematical simulation model of dynamic parameters of a given hydraulic system. A designer can subsequently utilize maximal flexibility, maximal stiffness or required ratio of the mentioned hose properties. The measured hose isn't destructed and can be subsequently used in hydraulic systems. It is a big advantage of this method.

Keywords: Modulus of Elasticity, Hydraulic Hose, Oil, Non-Destructive Method.

\section{Acknowledgements}

The work presented in this paper was supported by a grant SGS "Zkoumání dynamiky tekutinových systémů" SP2015/95.

\section{References}

[1] VALÁŠEK, P. (2014). Mechanical Properties of Epoxy Resins Filled with Waste Rubber Powder. In: Manufacturing Technology. 2014, Vol. 14, No. 4, pp. 632-637. JEPU in Usti nad Labem. Czech Republic.

[2] ŽMINDÁK, M., MEŠKO, J., PELAGIC, Z., ZRAK, A. (2014). Finite element analysis of crack growth in pipelines. In: Manufacturing Technology. 2014, Vol. 14, No. 1, pp. 116-122. JEPU in Usti nad Labem. Czech Republic.

[3] MIČIAN, M., PATEK, M., SLÁDEK, A. (2014). Concept of repairing branch pipes on high-pressure pipelines by using split sleeve. Manufacturing Technology, Vol. 14, No. 1, pp. 60-66. JEPU in Usti nad Labem. Czech Republic.

[4] FITCH, E., C., (1997). Hydraulic Component Design and Selection. p. 633. BarDyne, Inc Oklahoma. USA.

[5] HRUŽÍK, L., VAŠINA, M. (2009). Nondestructive Testing for Experimental Determination of Elastic Modulus of Rubber Hoses. Acta Hydraulica et Pneumatica 1(7):12-16.

[6] HRUŽÍK, L., VAŠINA, M. (2008). Experimentální stanovení modulu pružnosti hadic. Jemná mechanika a optika 5:133-135.

[7] BUREČEK, A. (2013). Fluid Structure Interaction in Case of Non-Stationary Flow. Doctoral thesis, VŠB - Technical University in Ostrava, Czech Republic.

[8] SU, C., LI, T. (2014). Study on Springback Rule of AZ31B Magnesium Alloy Axisymmetric Part's Warm Single Point Incremental Forming without Mould. In: Manufacturing Technology. 2014, Vol. 14, No. 4, pp. 626-631. JEPU in Usti nad Labem. Czech Republic.

[9] XU, J., GU, L., LUO, S. (2014). Dynamic Analysis for High-speed Cutters of Five-axis CNC Milling Machine. In: Manufacturing Technology. 2014, Vol. 14, No. 4, pp. 643-650. JEPU in Usti nad Labem. Czech Republic.

[10] HRUŽÍK, L., VAŠINA, M., BUREČEK, A. (2013). Evaluation of Bulk Modulus of Oil System with Hydraulic Line. In: EPJ Web of Conferences 2013, Vol. 45, article No. 01041. Polypress s.r.o. in Liberec. Czech Republic.

[11] HRUŽÍK, L., BUREČEK, A., VAŠINA, M. (2013). Measurement and Numerical Simulation of Hydraulic Hose Expansion. In: 5th International Scientific and Expert Conference of the International TEAM Society, pp. 222225. Stevepress, Ltd. in Prešov. Slovakia. 